\title{
$11: 33870412-33836701$
}

National Cancer Institute

\section{Source}

National Cancer Institute. 11: 33870412-33836701. NCI Thesaurus. Code C44997.

Physical location of LMO2_Gene 